\title{
Monarchiści i ich symulacje polityczne w maju-lipcu 1920 roku. Memoriały płk. Maxa Bauera i gen. Wasilija Biskupskiego
}

Zarys treści: Przedmiotem edycji są dwa monarchistyczne projekty: niemiecki (memoriał płk. sztabu generalnego Maxa Bauera ogłoszony na Zjeździe monarchistów w Budapeszcie 20 czerwca 1920) i rosyjski (Memoriał nr 1 gen. Wasilija Biskupskiego ogłoszony na zjeździe monarchistów w Budapeszcie 8 lipca 1920). Autorka opracowania ukazuje złożony kontekst funkcjonowania swego rodzaju międzynarodówki monarchistycznej po zakończeniu pierwszej wojny światowej. Stawia hipotezę, iż poza przygotowywaniem planów walki z bolszewikami, efektem aktywności monarchistów niemieckich i rosyjskich w tym czasie miała być destrukcja konkurencyjnego programu wschodniego Józefa Piłsudskiego. Problemy mogące wynikać z polskiej polityki wschodniej znikły jednak dzięki polskim decyzjom podporządkowania ZCZW władzom w Warszawie, co skutkowało utratą zainteresowania Niemców dla ruchu monarchistycznego, traktowanego jako doraźne narzędzie walki politycznej.

Outline of content: This study focuses on two monarchist projects: one German (memorial by Colonel of General Staff Max Bauer announced at the Monarchist Congress in Budapest on 20 June 1920) and one Russian (memorial by General Vasiliy Biskupskiy, announced at the Monarchist Congress in Budapest on 8 July 1920). The author of the study defines the complex context of the functioning of the „monarchist international” after the end of World War I. She hypothesises that, aside from plans on how to counter the Bolshevik threat, the main outcome of the activity of German and Russian monarchists at that time was to be the destruction of Józef Piłsudski's rival „Eastern programme”. However, the problems that could have arisen in consequence of the Polish Eastern policy never saw the light of day by reason of the decision subordinating the Civilian Administration of the Eastern Territories to the authorities in Warsaw, which resulted in a loss of interest in the monarchist movement in Germany, as it was seen as a temporary tool of political struggle.

Słowa kluczowe: zjazdy monarchistyczne 1920, memoriał płk. Maxa Bauera, Memoriał nr 1 gen. Wasilija Biskupskiego, polska polityka wschodnia 1920; ziemie b. Wielkiego Księstwa Litewskiego po I wojnie światowej 
Keywords: congresses monarchist 1920, proclamation of Colonel Max Weber, proclamation of General Vasily Biskupski, eastern policy Second Republic of Poland, The Grand Duchy of Lithuania after First World War

Monarchistyczną arenę polityczną po Wielkiej Wojnie zdominowali Niemcy i Rosjanie. Poruszając kwestię współpracy monarchistów rosyjskich i niemieckich w latach 1918-1921, nie można tracić z oczu podstawowego faktu - na frontach Wielkiej Wojny Rosjanie i Niemcy stali jednak po dwóch liniach frontu. W Wersalu interesów Rosji skutecznie pilnowały państwa Ententy, Niemcy zaś tę wojnę formalnie przegrały. Na Wschodzie, w praktyce, Niemcy jednak Wielkiej Wojny bynajmniej nie przegrały. W sposób zakulisowy i nadzwyczaj skuteczny nadal walczyły np. o strefę swych wpływów w basenie Morza Bałtyckiego ${ }^{1}$.

Niemcy jeszcze w trakcie I WW wykorzystali orędzia Benedykta XV i idee Wilsona we własnym interesie. Daleko im było od filantropii, której beneficjentami mieliby być mieszkańcy ziem byłego Wielkiego Księstwa Litewskiego czy ziem ukrainnych.

Realną władzę w Europie od 1918 r. dzierżyły głowy niekoronowane. Fizyczna likwidacja domu Romanowych wstrząsnęła publicznością, ale życie toczyło się dalej. Powszechnemu lekceważeniu posunięć monarchistów sprzyjała (i sprzyja nadal) mała skuteczność ich działań dla nich samych. Efektem poczynań monarchistów była po prostu destrukcja, a nie konstrukcja.

Monarchistów wszelkiej proweniencji początkowo traktowano jako margines sceny politycznej. W roku 1918 Niemcy en masse postrzegani byli w Warszawie przez opiniotwórcze warszawskie kręgi polityczne raczej jako promotorzy odbudowy polskiej państwowości niż jako jej konkurent. (Podobnie postrzegał ich rolę - niestety - Roman Skirmunt). Tymczasem projekt „Mitteleuropa” był po prostu projektem konkurencyjnym w stosunku do koncepcji Rzeczypospolitej Obojga Narodów i paradoksalnie - w istocie rzeczy współgrał z narodową koncepcją „nowoczesnej” XX-wiecznej Polski. Wydaje się, że polscy politycy skupieni wokół Tymczasowej Rady Stanu i Rady Regencyjnej tak skoncentrowali swą uwagę na głośnej pracy Friedricha Naumanna wydanej w 1915 r., iż tego nie dostrzegli.

Niebezpieczeństwo wynikające z polityki niemieckiej dostrzegł natomiast z odległej Moskwy Aleksander Lednicki. „Le Temps” z 2 X 1918 r. podał informacje jakoby „un des polonais qui se trouvent en Russie” nakłaniał rządy koalicji do ogłoszenia nowej deklaracji w sprawie polskich granic sięgających do Morza Bałtyckiego. O tej jego inicjatywie pisano też w "L'Humanité” z 5 X 1918 roku. Zabiegi Lednickiego - jak wiadomo - spełzły na niczym. W numerze 388 pisma „Journal de Geneve” redakcja omówiła plany Niemiec na Wschodzie przyjęte jeszcze w grudniu 1917 roku. Wg informacji redakcji „Journal de Geneve”, cesarz Karol, król Węgier, miał zostać królem Polski, Polska zaś „wzmocniona” miała zostać odzyskaniem Galicji.

1 J. Gierowska-Kałłaur, Question of the access of restored Polish State to the Baltic See in opposition to German interests. Marea Loc al Memoriei si al Desfasurarilor Geostrategice. Asociatia pentru Dialog Intercultural si Studii Istorice, red. Florin Anghel, Gabriel Stalian Manea, Metin Omer, Editura CETATEA se SCAUN, Targoviste 2014, s. 225-238. 
(To „wzmocnienie” z jednej strony odcinało przyszłą Polskę od Morza Bałtyckiego, $\mathrm{z}$ drugiej - rzucało pochodnię pomiędzy z jednej strony Rosjan aspirujących do swojej hegemonii na ziemiach ukrainnych, z drugiej - walczących o swoje Ukraińców, z trzeciej - walczących o swoje Polaków).

Dla analityków berlińskich wszelkiej orientacji łatwa była do przewidzenia przyszłość po wojnie, i to w każdej sytuacji, jaką by ta wojna się nie zakończyła. Konkurentem do przechwycenia roli moderatora na ziemiach b. Wielkiego Księstwa Litewskiego (czyli także w basenie Morza Bałtyckiego) w chwili zakończenia walk mogli stać się tylko Polacy. Często cytowana jest w literaturze wypowiedź (z początku stycznia 1917 r.) wysokiego urzędnika niemieckiej administracji wojskowej w okupowanej Litwie, von Beckeratha: „Polacy są na Litwie jedynym elementem posiadającym wybitne kwalifikacje polityczne i twórcze. Jeśli możliwe jest rządzić bez nich w czasie wojny, to w czasie pokoju rządzenie przeciw nim staje się być nie tylko trudnym, ale nawet niebezpiecznym"2. Jeśli uwzględnimy fakt, iż w czasie współczesnym Beckheratowi pod pojęciem Litwa mieściła się Litwa historyczna to mamy do czynienia z najkrótszą recenzją nie tylko polskiego, ale i litewskiego oraz białoruskiego „potencjału” na terenie Wilna i całego Ober-Ost.

Dzięki zręcznej polityce specjalnej prowadzonej na ziemiach b. Wielkiego Księstwa Litewskiego w zasadzie w basenie Morza Bałtyckiego Niemcy spacyfikowali niebezpieczeństwo dla swoich interesów ze strony Polski. Z premedytacją siali ziarno rodzące rozdźwięki pomiędzy innymi naturalnymi sojusznikami regionu usytuowanego pomiędzy Rosją (bez względu na jej kolor) a Niemcami i ich sojusznikami. I nie chodziło tu tylko o Chełmszczyznę.

Rusini ówcześni, czyli po prostu Ukraińcy, nie mając zresztą specjalnie wyboru, nie bez przyczyny akurat Niemców postrzegali jako polityków najbardziej spolegliwych wobec swoich politycznych ambicji i terytorialnych roszczeńn ${ }^{3}$.

Celem zarówno polityki niemieckiej jak i rosyjskiej, dodajmy wszelkich orientacji, było zantagonizowanie mieszkańców ziem b. Wielkiego Księstwa Litewskiego z tamtejszymi Polakami zagrażającymi zarówno niemieckiej, jak i rosyjskiej racji stanu. Pionierami tej polityki, na długo przed wybuchem I wojny, byli Rosjanie, czego widomym dowodem są antypolskie karykatury zamieszczane chociażby w petersburskim piśmie „Nowoje Wremja” z 1907 roku$^{4}$. Odezwa Mikołaja II pomogła Polakom w uzyskaniu w oczach Rosjan pewnej, ograniczonej jednak podmiotowości.

2 Za P. Łossowski, Konflikt polsko-litewski 1918-1920, Warszawa 1996, s. 12.

3 W. Mędrzecki, Niemiecka interwencja militarna na Ukrainie w 1918 r., DiG, Warszawa 2000, ss. 330.

4 Ponad pół pierwszej stronicy numeru 11234 z 23 (6) czerwca 1907 zajmuje kolorowa karykatura czterech postaci kroczących pomiędzy zbitym tłumem klęczących chłopów w świtkach bijących im pokłony. Pierwszy kroczy R. Dmowski w meloniku i płaszczu wymachując olbrzymim batem, za nim drobi w sutannie i okularach modlący się J. J. Gralewski o suchotniczym wyglądzie. Trzecia postać to podpierający się kosturem J. Bielawski w chłopskiej sukmanie, butach i portkach. Pochód zamyka elegancko odziany hrabia G. R. Potocki z monoklem w oku. Tytuł tej karykatury to „, Sen polskiego „Koła” w wiosenna noc”, a podpis pod nią - ,, Tryumfalny pochód w Guberni Mińskiej”. 
Obecność monarchistów rosyjskich na terenie państwa niemieckiego po rewolucji bolszewickiej i niekomfortowa sytuacja, w jakiej się wówczas znajdowali, stanowiła dla Niemców z jednej strony niebezpieczeństwo, z drugiej - znakomitą okazję do realizacji celów polityki niemieckiej w niesprzyjających im, powersalskich warunkach.

Rozbieżnych celów i punktów zapalnych pomiędzy Niemcami i Białymi Rosjanami znaleźć można by wiele. Rosjanie żywotnie byli zainteresowani pozostającymi w roku 1918 w strefie wpływów niemieckich krajami bałtyckimi i uzyskaniem dla przyszłej Rosji całorocznego dostępu do Morza Bałtyckiego. Oczy polityków rosyjskich - i to bez względu na orientację polityczną - tradycyjnie zwracały się również ku ziemiom ukraińskim, gdzie po traktacie brzeskim bez wątpienia dominował długofalowy wpływ polityki niemieckiej.

Niemcy z kolei, oprócz dążenia do utrzymania hegemonii na Bałtyku, dużą wagę przykładali również do swojej ekspansji na południu - na ziemie austriackie i czeskie. Sytuacja wewnętrzna w Rosji oczywiście nie była dla Niemców tak centralnym punktem zainteresowania jak dla Rosjan. O ziemie pozostające pod wpływem polityki niemieckiej, do których aspirowali Rosjanie - ziemie ukrainne - Niemcy mogli się bić, mogli utrzymywać Rosjan w stanie niepewności co do swoich planów - lub ekonomicznie wyzyskać do szczętu, a po ewentualnej niekorzystnej dla nich odmianie sytuacji - planować ich odstąpienie.

Niemająca dostępu do żadnego z mórz Biała Ruś nie była obiektem takiego zainteresowania polityki niemieckiej, jakim cieszyły się ziemie obecnej Ukrainy i Litwy.

Dwie dominujące na arenie monarchistycznej narodowe grupy - rosyjska i niemiecka - w latach 1918-1920 miały różny potencjał.

Analizy sytuacji nie ułatwia fakt, iż pomiędzy tymi dwiema grupami reprezentującymi przeciwstawne państwowe interesy - w charakterze niemal „zakładników" - miotała się liczna grupa mieszkańców ziem nadbałtyckich znajdujących się dosłownie w krzyżowej sieci uzależnień. Ekonomicznie ludzie ci związani byli z akwenem Morza Bałtyckiego, węzłami krwi nie tylko z Berlinem, ale i z Rosją, politycznie, a nieraz i mentalnie - z Rosją, ale też z Niemcami. Ich pierwszoplanowym celem musiało być wykorzystanie wszelkich sposobności i koneksji, by przede wszystkim samemu przetrwać fizycznie i ekonomicznie oraz - w miarę możliwości - w powojennej Europie odzyskać utraconą pozycję. Pomijając aspekt emocjonalnego „braterstwa krwi” mieszkańców Meklemburgii, Szlezwik-Holsztynu, Bremy czy pozostałych krain Rzeszy z Niemcami bałtyckimi, celem wojennym (i powojennym) państwa niemieckiego konsekwentnie była ekspansja, i to pomimo zmiennej, więcej lub mniej sprzyjającej sytuacji. Po Traktacie Wersalskim sam fakt istnienia Niemców bałtyckich mógł stanowić ważny czynnik sprzyjający instrumentalnemu wykorzystaniu ruchu monarchistycznego przez polityków niemieckich dla realizacji własnych celów politycznych.

Polityka jest sztuką wykorzystywania możliwości. Alians monarchistów rosyjskich i niemieckich (w tym Niemców bałtyckich) z perspektywy Berlina w roku 1920 wydawać się musiał nieunikniony i pierwszoplanowym zadaniem polityków 
berlińskich musiało stać się dążenie do przejęcia kontroli nad rozwojem wydarzeń oraz wykorzystanie sytuacji we własnym, niemieckim, państwowym interesie.

Oczywiście - oficjalnie deklarowano wzajemną rosyjsko-niemiecką współpracę, ale równolegle otwarty był cichy „drugi front” - gra o wpływy na terytoriach Europy Środkowo-Wschodniej pomiędzy „przegranymi” Niemcami a wysadzoną z siodła przez bolszewików Rosją, która miała nadzieję na odzyskanie swej utraconej pozycji.

Do roli moderatora na tym terenie aspirowała też polityka wschodnia Józefa Piłsudskiego adresowana nie tyle do polityków, ile do wszystkich mieszkańców byłego Wielkiego Księstwa Litewskiego. Zanim jeszcze dało się w Berlinie zauważyć (i zdyskontować) równoległe funkcjonowanie dwóch przeciwstawnych koncepcji polskiej polityki wschodniej, Niemcy prowadzili politykę zantagonizowania mieszkańców ziem b. Wielkiego Księstwa Litewskiego, w celu osłabienia elementu najsilniejszego na tych ziemiach - Polaków. W wyniku tej polityki grupa narodowa polska była jedyną z grup narodowościowych Wilna, która do końca okupacji niemieckiej nie uzyskała zgody na zwołanie swojego zjazdu narodowego. W latach 1919-1920 dzieło dalszej destrukcji społeczeństwa b. Wielkiego Księstwa Litewskiego kontynuowali, zresztą w najlepszej wierze, iż czynią to dla dobra Polski, polscy polityczni oponenci Naczelnika Państwa ${ }^{5}$.

Trzeba wyraźnie powiedzieć - działania monarchistów w roku 1920 nie były tak bezowocne, jak to się powszechnie przyjmuje. Destrukcja koncepcji politycznych to też efekt. Wiele wskazuje na to, że aktywność monarchistów mogła zniweczyć szanse na powodzenie międzynarodowej akcji białorosyjskiego centrum. Działania monarchistów mogły mieć też duży wpływ na destabilizację i tak niestabilnej sytuacji polityków ukraińskich i białoruskich, musiały zaważyć na ukraińskich, a przede wszystkim białoruskich wyborach.

Działania podejmowane przez monarchistów mogły mieć wpływ na zaniechanie jakichkolwiek demonstracyjnych deklaracji i idących za nimi posunięć ze strony nastawionej propolsko części polityków białoruskich. Jak wiadomo, 6 marca $1920 \mathrm{r}$. Ententa zabroniła Polsce przeprowadzenia plebiscytu ${ }^{6}$ zapowiedzianego w Odezwie Wileńskiej i Naczelnik Państwa Polskiego szukał innego sposobu realizacji obietnicy złożonej Mieszkańcom b. Księstwa Litewskiego, z której sam przecież nigdy się nie wycofał. Potrzebował politycznego wsparcia ze strony Litwinów, Białorusinów i Ukraińców. Sojusz z Petlurą był jedynym atutem. Wydarzenia z końca sierpnia 1919 r. w Kownie, jak też wielomiesięczne przygotowania do podpisania traktatu rosyjsko-litewskiego (12 lipca 1920) gwarantowały antagonistom polskiej państwowości brak współpracy polsko-litewskiej. Niewiadomą pozostawało zachowanie Białorusinów.

5 Problem ten omówiłam w swojej pracy o Zarządzie Cywilnym Ziem Wschodnich. J. Gierowska-Kałłaur, Zarząd Cywilny Ziem Wschodnich (9 lutego 1919-9 września 1920), Wydawnictwo Neriton \& Instytut Historii PAN, Warszawa 2003, ss. 447.

6 Tekst Noty w J. Gierowska-Kałłaur, Zarząd Cywilny Ziem Wschodnich..., s. 92. 
Demonstracyjne poparcie Piłsudskiego przez pozostających w kontakcie z Antonem Łuckiewiczem i BRL członków Rady Najwyższej, nawet poparcie niemające żadnego przełożenia na realnie toczący się rozwój wypadków, dawałoby Piłsudskiemu drugi atut w polsko-polskim dyskursie, nie wspominając już o tym, że bardzo oczyściłoby sytuację w stosunkach polsko-białoruskich na przyszłość.

Wspierani przez Belweder politycy białoruscy w żaden sposób nie wsparli Piłsudskiego w polsko-polskim sporze o kształt polskiej polityki wschodniej. Wydaje się, że znaczący udział w tym zaniechaniu miał "niemiecki monarchista Max Bauer”. Zapoczątkowaną przez Maxa Bauera intrygę podjęli Biali Rosjanie, traktujący Białorusinów jako niesfornych poddanych swojego Imperium. Dzieło ostatecznej destrukcji podstawowego wariantu polityki wschodniej Józefa Piłsudskiego $\left(\mathrm{ZCZW}^{7}\right)$ zostało ostatecznie dokonane 1 czerwca 1920 r., bez wątpienia polskimi rękoma. Tego dnia ZCZW stracił swą podmiotowość na arenie politycznej. Zarząd Cywilny Ziem Wschodnich został podporządkowany Prezydium Rady Ministrów w Warszawie. Po długiej walce Józef Piłsudski ostatecznie stracił narzędzie mające mu służyć - w zamyśle pierwotnej koncepcji - do realizacji koncepcji federacyjnej.

W roku 1920 odbyło się wiele konferencji i zjazdów monarchistów europejskich, w których aktywnie uczestniczyli monarchiści wszystkich narodowości. Choć ludzi tych łączyło dążenie do restauracji monarchii w Europie, to jednak ich interesy ekonomiczne i narodowe pozostawały sprzeczne. Główną rolę odgrywali Rosjanie i Niemcy, którzy, jak wspomniano, celów rozbieżnych mieli sporo, ale których wspólnym projektem mogło stać się zneutralizowanie, wyeliminowanie z gry bądź znaczne osłabienie wspólnie im zagrażających podmiotów politycznych. Interesom zarówno rosyjskim, jak i niemieckim oprócz bolszewików zagrozić mogło wówczas jedynie Państwo Polskie, o ile realizowałoby politykę swego Naczelnika.

Poniżej prezentuję dwa odnalezione memoriały. Pierwszy ogłoszony przez monarchistów niemieckich (Memoriał płk. Maxa Bauera), drugi - przez środowisko monarchistów rosyjskich (Memoriał nr 1 generała Wasilija Biskupskiego).

W sposób zasadniczy różni je moment, w którym powstały. Dziesięć tygodni początków lata $1920 \mathrm{r}$. było okresem bogatym w bardzo istotne wydarzenia zmieniające w sposób znaczący kontekst polityczny w regionie. Kilkutygodniowa różnica w czasie powstania obu memoriałów jest istotna.

Opracowanie sygnowane przez Maxa Bauera powstawało jako pierwsze, jeszcze w maju 1920 roku. Czyli przed podporządkowaniem ZCZW Radzie Ministrów w Warszawie i przed rozciągnięciem na Ziemie Wschodnie jurysdykcji warszawskiej Najwyższej Izby Kontroli.

Memoriał gen. Wasilija Biskupskiego, ogłoszony został dopiero w lipcu 1920 r., po podporządkowaniu ZCZW Radzie Ministrów i Najwyższej Izbie Kontroli w Warszawie, w nowej sytuacji militarnej, gdy Armia Czerwona już parła na zachód.

Memoriał Biskupskiego postrzegam nie tylko jako rosyjską odpowiedź na Memoriał Bauera, ale również uważam za przejaw dążenia Rosjan do przejęcia

7 Zob. szerzej J. Gierowska-Kałłaur, Zarząd Cywilny Ziem Wschodnich... 
inicjatywy w ruchu monarchistycznym. Memoriał ten, wiele na to wskazuje, nie spotkał się z niemiecką kontrakcją polityczną. W lipcu 1920 r. powszechnie znany rozwój wypadków militarnych wydawało się wyeliminował już Polaków z gry politycznej o przyszły status w regionie i w sposób oczywisty polska polityka nie stanowiła już dla polityki niemieckiej zagrożenia.

Od tej pory ruch monarchistyczny de facto stał się ruchem w zasadzie nieco „celebryckim” i widoczne jest w nim wyraźnie swego rodzaju „moderatorstwo” Białych Rosjan. Grupy tracącej z każdym miesiącem realne szanse na odbudowanie swego Imperium i to pomimo wsparcia, które przyszło (od lutego 1921 r.) z dość nieoczekiwanej strony - z Watykanu. Monarchiści niemieccy stali się zaś w swoim kraju dość liczną, ale niszową grupą, niemającą już realnego politycznego znaczenia.

Stosunki litewsko-polskie nie były przedmiotem żadnych monarchistycznych symulacji politycznych w pierwszych miesiącach lata 1920 roku. Udaremniony, jak wiele na to wskazuje, przez polską prawicę, kowieński zamach stanu w sierpniu 1919, wspierany (o ile nie inspirowany) przez obóz belwederski ${ }^{8}$, a także przygotowywany przez pierwsze półrocze 1920 traktat litewsko-sowiecki gwarantowały, iż z Polakami Litwini się nie porozumieją.

W monarchistycznej grze maja-czerwca roku 1920 pionkami w grze byli pozostali reprezentanci tych, pod których adresem Józef Piłsudski prowadził wówczas swą politykę wschodnią, czyli politycy Białoruskiej Republiki Ludowej.

Uważam, że inicjatywa płk. Maxa Bauera miała na celu stworzenie politycznej alternatywy przede wszystkim dla aliansu polsko-ukraińskiego, a tym samym osłabienie sojuszu Piłsudski-Petlura (kwiecień 1920), co mogło wzmocnić kolejnego przegranego polityka tej epoki hetmana Skoropadskiego. Dla niemieckiej racji stanu istotne też musiało być działanie prewencyjne na odcinku białoruskim powstrzymanie Antona Łuckiewicza od ewentualnego, jeszcze możliwego, zbliżenia z Piłsudskim. Mało prawdopodobne było, by Rada Białoruskiej Republiki Ludowej, konsekwentnie dotąd prowadząca politykę antypolską, zmieniła swe zapatrywania. Ale w kontakcie z Belwederem pozostawała Rada Najwyższa (a za jej pośrednictwem Anton Łuckiewicz) - Rada konsekwentnie wspierana z Warszawy do lata 1920 r., i konsekwentnie do lata 1920 r. uchylająca się od jakiegokolwiek chociażby demonstracyjnego poparcia polityki deklarowanej przez Józefa Piłsudskiego.

W lipcu 1920 r. istniała diametralnie już odmienna od maja sytuacja militarna i polityczna. Politycy białoruscy (Anton Łuckiewicz i Rada Najwyższa) de facto nie mieli już żadnej możliwości manewru politycznego, który leżał jednak uprzednio w zasięgu ich możliwości. Z punktu widzenia Berlina środowisko polityków białoruskich antyszambrujące $\mathrm{w}$ berlińskich urzędach, bez wątpienia nie miało już groźnej dla niemieckich planów „polskiej alternatywy”. A Piłsudski za sprawą

8 „Depozyty” Walerego Sławka przechowywane w Moskwie. („Biuro Detaszowane Oddziału II Naczelnego Dowództwa 1919”), „Studia z Dziejów Rosji i Europy Środkowo-Wschodniej” 47, 2012, s. 208-272. http://www.sdr-ihpan.edu.pl/files/10_gierowska.pdf [dostęp 21 I 2015]. 
kunktatorstwa Rady Najwyższej nie miał już na odcinku białoruskim żadnego pola manewru dyplomatycznego.

Z datą 26 maja 1920 r. ukazał się rozkaz Naczelnego Wodza Wojsk Polskich do Pana Komisarza Generalnego Ziem Wschodnich w sprawie przygotowania projektów ustaw, regulujących władanie ziemią w myśl zasad reformy rolnej, uchwalonych przez Sejm Ustawodawczy Rzeczypospolitej Polskiej w dniu 10 lipca 1919 roku9 .

15 czerwca 1920 r. nieświadom jeszcze grozy sytuacji na froncie Piłsudski przyjmował Borysa Wiktorowicza Sawinkowa w Belwederze...

Akcjonariuszami powstałego w maju 1920 r. z inicjatywy niemieckiej „Spisku Monarchistów Europejskich” były, oprócz Niemiec i Austrii, Rosja „z państwami ościennymi - Ukrainą i Białorusią" oraz Bułgaria, Turcja, Irlandia i Węgry.

Niezmiernie znaczącą postacią wśród inicjatorów założycieli tego Spisku był pułkownik Max Hermann Bauer (1869-1929) ${ }^{10}$, autor pierwszego z odnalezionych Memoriałów. Max Bauer już w 1905 r. został powołany do niemieckiego sztabu generalnego i znany jest powszechnie jako ekspert w taktyce artylerii, a sławę ugruntowało mu zniszczenie fortu Liege w Belgii w 1914 roku. W lipcu 1915 r. został szefem sekcji I Sztabu Generalnego rezydującego w „Małym Berlinie” (tak Pszczynę określały gazety pruskie z epoki) w Kwaterze Głównej usadowionej na pierwszym piętrze pszczyńskiego budynku Paleja ${ }^{11}$. Jak wiadomo, pierwszą z najważniejszych osób w tym Sztabie był Generalfeldmarschall Paul von Beneckendorff Hindenburg ${ }^{12}$. Drugą - prawa ręka Hindenburga gen. Erich Ludendorff ${ }^{13}$. Po wymienionych trzecią najwyższą stopniem w Sztabie osobą byl pułkownik Max Bauer ${ }^{14}$, ulubieniec Ludendorffa i jego lącznik pomiędzy nim a Gustavem Stresemannem.

9 Opublikowany w „Dzienniku Urzędowym Zarządu Cywilnego Ziem Wschodnich”, Rok II, nr 42(86), Wilno, dnia 4 czerwca 1920. I. 1056.

10 B. Schwertfeger, Bauer Max, [w:] Neue Deutsche Biographie (NDB), Band 1, Duncker \& Humblot, Berlin 1953, ISBN 3-428-00182-6, s. 643 f. (Digitalisat) zob. też A. Vogt, Oberst Max Bauer. Generalstabsoffizier im Zwielicht. 1869-1929, Biblio Verlag, Osnabrück 1974, ISBN 3-7648-0946-9. (Studien zur Militärgeschichte, Militärwissenschaft und Konfliktforschung 6).

11 Od jesieni 1914 do lutego 1917 r. książę pszczyński udostępnił budynek Paleja na potrzeby sztabu Kwatery Głównej wojsk cesarza niemieckiego Wilhelma II. Sam monarcha zamieszkał w pobliskim pałacu księcia.

12 Paul von Beneckendorff Hindenburg (1847-1934), 1914-1915 dowódca frontu wschodniego, feldmarszałek, szef sztabu Kwatery Głównej (1916-1918), kierował z Pszczyny operacjami wojskowymi wszystkich frontów niemieckich.

13 Erich Ludendorff (1863-1937), generał i polityk nacjonalistyczny; na początku I wojny światowej szef sztabu niemieckiej 8. Armii w Prusach Wschodnich, następnie szef sztabu frontu wschodniego, w latach 1916-1918 kwatermistrz generalny.

$14 \mathrm{~W}$ budynku pracowali: adiutant v. Hindenburga, kpt. von Bismarck, kapitanowie: Bulcke, Gabriel, v. Ilsemann oraz porucznicy: Thoemissen, v. Poseck, mjr v. Vothard- Bockelberg, kpt. Frhr v. D. Bussche Poten, kpt. hr. Dohna, kpt. Fischer, mjr Wetzell, kpt. Iosupeit, por. v. Pentz Freuenfeld, kapral Lengfeld. Kancelaria: sierżanci: Kempin, Hubner, kaprale: Maenncher i Franke; pokój 18 - mjr Wagner, kpt. von Harbon, kpt. Geyer, kpt. von Gossler; pokój 19 - płk Bauer; pokój 20 - mjr Frahnert i kpt. Hesse. Za: Gmach Generalnej Dyrekcji Dóbr Książęcych w Pszczynie, Biuro Rachunkowe GK Sp. 
Niemiecki sztab generalny zaprawiony był w prowadzeniu cichej walki politycznej ze swoimi „sojusznikami” w bardzo niekonwencjonalny sposób. Współpraca austriacko-węgiersko-niemiecka w trakcie I WW, jak powszechnie wiadomo, była co najmniej „szorstka”. Sprawujący faktyczną władzę w Niemczech marszałkowie Ludendorff i Hindenburg prowadzili kampanię dezinformacyjną wymierzoną przeciwko swojemu „sojusznikowi”, licząc na dalsze osłabienie pozycji Karola I we własnym kraju. W niemieckim Naczelnym Dowództwie powstała specjalna komórka kierowana właśnie przez płk. Maxa Bauera, której zadaniem było systematyczne oczernianie Karola I, którego oskarżano nawet o... alkoholizm. Jednym słowem, cała dotychczasowa kariera Maxa Bauera świadczyła o tym, że był w roku 1920 znaczącą postacią nie tylko w niemieckim ruchu monarchistycznym.

22 czerwca 1920 r. pułkownik Bauer przedstawił w Budapeszcie przygotowywany w miesiącach wcześniejszych Memoriał. W memoriale zostały sformułowane cele, organy wykonawcze i sposób finansowania „Spisku Monarchistów Europejskich”, którego akcjonariusze zobowiązali się do tak ścisłej konspiracji, iż zaakceptowali zapowiedź karania śmiercią każdego, kto naruszy tajemnicę. Podjęte postanowienia zostały zatwierdzone przez budapesztańską „Tajną Konferencję Monarchistów”. Główna kwatera „Spisku” miała się mieścić w Budapeszcie. Projekt przedstawiony przez pułkownika Bauera zapewniał hegemonię Niemcom, a konkretnie Bawarii. Pułkownik Bauer ostrze swego projektu skierował przeciwko Entencie, ale udało się też zatwierdzić plan agresji przeciw Austrii i Czechosłowacji. Ciekawy był przewidziany przez pułkownika Bauera sposób finansowania tego przedsięwzięcia. „Utrzymanie Centralnego Komitetu Wykonawczego, również i subsydia poszczególnym „organizacjom, kierownikom, wydatki tajne (ochrona) pokrywa się pożyczka wewnętrzna Rządem Białej Rusi. (Drukowanie pieniędzy na Węgrzech) Do tego ustanawia się porozumienie między przedstawicielami Białej Rusi i Niemiec" (patrz: Memoriał płk. Bauera).

Tak więc Niemcy (trudno traktować pułkownika Bauera jedynie jako monarchistę) w maju 1920 r. nie tylko „ograli” pozostających jednak w lepszej sytuacji międzynarodowej monarchistów rosyjskich (strata czasu grała na niekorzyść tych ostatnich i stopniowo coraz bardziej uzależniała ich od Niemców), ale też - przy okazji - bardzo instrumentalnie potraktowali idealizujących stosunek polityków niemieckich do Białej Rusi berlińskich polityków BRL. Nasuwają się hipotezy badawcze.

- Czy zawiązany w maju 1920 r. „Spisek Monarchistów Europejskich” i memoriał pułkownika Bauera nie były wcielonym w życie projektem komórki specjalnej w Naczelnym Dowództwie niemieckim?

- Czy wspomniany w tekście „Rząd Białej Rusi” nie był tu tylko „przystawką polityczną" odwracającą uwagę od meritum sprawy w trwającej niemiecko-rosyjskiej rozgrywce?

z o.o. - Grażyna Kliś. Opracowanie: Zygmunt Orlik. http://www.biurogk.com/gmach_palais_historia. html [dostęp 19 I 2015]. 
- Czy element białoruski tej układanki nie został tu umieszczony przez polityków niemieckich w celu odciągnięcia uwagi polityków BRL od kuszącej ich polityki Józefa Piłsudskiego?

Dalsze losy pułkownika Maxa Bauera wskazują wyraźnie, iż „monarchistą” był tylko i wyłącznie wczesnym latem 1920 roku. Jak podaje John P. Fox, do 1925 r. Max Bauer pracował jako konsultant wojskowy w ZSRR, Hiszpanii i Argentynie. Nie był mile widziany w Berlinie, podobno ze względu na udział, w swoim czasie, w puczu Kappa-Lüttwitza. W roku 1927 z inicjatywy Chińczyków Bauer odwiedził Czang Kaj-szeka, który zatrudnił go oficjalnie w charakterze swojego doradcy ekonomicznego, a de facto w charakterze doradcy wojskowego. Pułkownik Max Bauer zaaranżował kontakty handlowe Chin z tajną niemiecką misją wojskową w Nankinie. Doprowadził też do przekształcenia Akademii Whampoa w Centralną Akademię Wojskową z personelem złożonym z niemieckich doradców wojskowych i instruktorów. Aż dwudziestu niemieckich oficerów zostało zaproszonych do Chin w charakterze instruktorów szkolenia i wywiadu wojskowego. Okoliczności śmierci pułkownika Maxa Bauera są bardzo niejasne. Istnieje podejrzenie, iż Chińczycy celowo zarazili go ospą - faktem jest, że był jedyną osobą w całym regionie, która zachorowała na tę zakaźną chorobę. Pochowany został z honorami wojskowymi początkowo $\mathrm{w}$ Chinach, a po trzech miesiącach został przywieziony i pochowany w Świnoujściu (5 VIII 1929) ${ }^{15}$.

Wydaje się, że monarchiści rosyjscy szybko zorientowali się w roli, jaką im wyznaczyli wczesnym latem $1920 \mathrm{r}$. niemieccy gospodarze, i oczywiście sami chcieli przejąć inicjatywę. Rozwój sytuacji militarnej i politycznej w lecie $1920 \mathrm{r}$. wydawał się dla nich sprzyjający. Nikłość bazy źródłowej, jaką dysponujemy, pozwala w zasadzie tylko na stawianie hipotez.

Swój punkt widzenia na przyszły rozwój sytuacji w regionie Rosjanie przedstawiali w pięć tygodni po zneutralizowaniu ZCZW (co miało miejsce 1 czerwca 1920 r.) $\mathrm{i}$ - co istotne - już w okresie polskich klęsk militarnych. Monarchiści rosyjscy uważali Białorusinów za własnych poddanych (bo przecież nie obywateli) i nie kryli, iż widzą w nich jedynie rezerwuar mięsa armatniego, niewątpliwie przydatnego przy odbudowie rosyjskiego Imperium.

Kolejna tajna konferencja monarchistów miała miejsce pomiędzy 8 a 13 lipca 1920 r. w Budapeszcie, już po odebraniu przez Rząd w Warszawie samodzielności Komisarzowi Generalnemu Ziem Wschodnich, w dobie sukcesów militarnych Armii Czerwonej na froncie polskim. Gen. Biskupski przedstawił w trakcie jej obrad swój ściśle tajny Memoriał nr 1 (Memoriał płk. Biskupskiego).

Wśród rosyjskich monarchistów niepoślednie miejsce zajmował o jedenaście lat młodszy od Bauera generał Wasilij Wiktorowicz Biskupski (1878-1945), lubiany przy dworze cesarskim w Piotrogrodzie. Biskupski uczestniczył w wojnie rosyjsko-japoń-

15 Fox John P., Max Bauer: Chiang Kai-Shek's First German Military Adviser, „Journal of Contemporary History", Vol. 5 (No 4) (October 1970), p. 21-44. 
skiej, w trakcie której był ciężko ranny, do czynnej służby wg niektórych źródeł rosyjskich miał wrócić dopiero w roku 1914. Jednak według informacji Attache Wojskowego Państwa Polskiego w Finlandii (L.dz. 188 poufne z 5 X 1919 r.), płk. M. Pożerskiego ${ }^{16}$, do 1912 r. Biskupski służył w b. pułku konnej gwardii w Piotrogrodzie, gdzie połowę stanowili Niemcy. O Biskupskim pisała z sentymentem Zofia Potocka przy okazji obrony Landwarowa Tyszkiewiczów przed Niemcami w 1915 roku. Biskupski dowodził irkuckim pułkiem w Rydze, a w czasie rewolucji udał się pod opiekę Niemców. W 1918 przeszedł na służbę do ukraińskich wojsk hetmana Pawła Skoropadskiego. Od 29 kwietnia do 18 grudnia 1918 był nawet naczelnym dowódcą armii ukraińskiej. W 1919 r. wyemigrował do Niemiec i - wg Wołkowa ${ }^{17}$ - objął funkcję przewodniczącego Rządu Zapadnoruskiego w Berlinie. Bezskutecznie starał się o przejęcie dowództwa ochotniczego korpusu gen. Rüdigera von der Goltza w państwach bałtyckich, i to pomimo składanych obietnic przeprowadzenia ataku na czerwoną Moskwę. W marcu 1920 r., podobnie jak płk Max Bauer, gen. Wasilij Biskupski (uczestniczył w nieudanym puczu Kappa-Lüttwitza. Z konceptu raportu z Paryża z 27 IX 1921 N 8334 rotmistrza Dowbora wynika, iż gen. Biskupski, mąż śpiewaczki Wielcewej, oficer dawnego konnego pułku gwardii, a następnie, irkuckiego pułku huzarów i jeden z najzdolniejszych dowódców jazdy w czasie wojny w połowie września 1921 został dokooptowany do składu Zwierzchniej Rady Monarchistycznej ${ }^{18}$.

Bez wątpienia gen. Biskupski uczestniczył w zjeździe monarchistów w Reichenfall w 1921 roku. Otrzymał polecenie utworzenia handlowego towarzystwa akcyjnego pod nazwą „Aufbau” 19 i 300000 mk w celu powiększenia kapitałów Zwierzchniej

16 Wymieniony dokument przechowywany jest w Rosyjskim Państwowym Archiwum Wojskowym (dalej: RGWA) w Moskwie w tzw. Fondzie Trofiejnym (Wcześniejsze nazwa „Osobyj archiw NKWD” oraz „Centr Chranienia Istoriko-Dokumentalnych Kollekcij”. Fond 308K, opis 9, teczka 647, k. 64).

17 S. W. Wołkow, Generaly i sztab-oficery russkoj armii. Opyt martirologa, Tom 1, Moskwa 2012, s. 127.

18 Naczelna Rada Monarchistyczna wyłoniona została przez Zjazd Monarchistów w Reichenwallu w składzie: Markow II, metropolita Antoniusz, ks. Szirinskija-Szichmatowa i Maslennikow. Rada miała prawo dokooptować 6 członków. W skład Rady weszli w tym trybie gen. Połowcew (Francja), Szulkin (SHS) oraz baron Taube (Niemcy). Programem Naczelnej Rady Monarchistycznej było zjednoczenie wszystkich monarchistów pod hasłem „za wiarę, ojczyznę i cesarza”, odrodzenie monarchii pod berłem Romanowych oraz ścisłe działanie z kościołem prawosławnym. Deklarowano wprowadzenie samorządu na bliżej nieokreślonych Kresach (część członków zaliczała Polskę do Kresów). Deklarowano w sposób niesprecyzowany rozwiązanie sprawy agrarnej. Członkowie Rady nie przewidywali żadnych kompromisów z nie-monarchistami. Planowali tworzenie organizacji wojskowych (oficerskich), ich celem było zachowanie armii gen. Wrangla. Źródłami finansowania Naczelnej Rady Monarchistycznej były ofiary dobrowolne, subsydia monarchistów niemieckich, i b. cesarzowej-wdowy; jak też dochody funduszu cerkiewnego.

19 Organizacja „Aufbau” z Centrum w Monachium była konspiracyjne zamaskowaną kadrową monarchistyczną organizacją wojskową licząca 6000 oficerów. Na jej czele stał gen. Gurko, a gen. Wasilij Biskupski był szefem sztabu. Aufbau dysponowała ostatecznie kapitałem $40000000 \mathrm{mk}$. Według informacji polskiego attaché wojskowego w Paryżu, sponsorem tej organizacji była grupa finansistów niemieckich z grupy Sinnesa. 
Rady Monarchistycznej drogą obrotu handlowego i zjednoczenia monarchistów pod szyldem „niewinnej firmy handlowej”.

Generał Biskupski poinformował zebranych w Budapeszcie w lipcu 1920 r., iż w Berlinie „od pewnego czasu już funkcjonuje” Centrum Wojskowe wraz z Naczelnym Dowództwem i „właśnie się wyłoniło” Centrum Polityczne. Generał Biskupski mimochodem też dodał, iż Rząd Białej Rusi (mowa o BRL) ,już pozostaje” w kontakcie z Naczelnym Dowództwem Centrum Wojskowego. Analiza aktualnej sytuacji w jakiej znalazły się „zwyciężone narody” czyli Wielka Rosja, Wielkie Niemcy i Wielkie Węgry doprowadziła gen. Biskupskiego do konstatacji, iż konieczna jest natychmiastowa akcja, a jej koordynacja winna znaleźć się w rękach monarchistów rosyjskich. Powoływał się nie tylko na obietnice współpracy ze strony Wrangla, ale podawał informacje o prowadzonych jakoby od maja $1920 \mathrm{r}$. konsultacjach z przedstawicielami „czerwonego $z$ wyglądu, faktycznie białego” sztabu generalnego w Moskwie.

Biskupski kładł duży nacisk na konieczność „przyciagnięcia do pracy” działaczy politycznych Ukrainy, Białej Rusi, Litwy i nawet Łotwy, jednym słowem „wszystkich niezbędnych elementów", które miały wykorzystać swój wpływ, jak też wpływ podległych im organizacji dla pracy na rzecz urzeczywistnienia planu odbudowy Rosji. Nowy ład, którego - nie ukrywał - beneficjentami miały być wyłącznie Wielka Rosja, Wielkie Niemcy i Wielkie Węgry zaprowadzić mieli „biali ochotnicy” rozproszeni w Estonii, w Niemczech, w Serbii i w Polsce - ale - uwaga „dokładnie oczyszczeni z elementów niemonarchistycznych". To oni mieli stanowić kadry nowej armii, żandarmerii i policji w przyszłej Rosji. Gen Biskupski rozwinął przed zebranymi wizję mającą cechy niemal przepowiedni politycznej. Szkopuł leżał w tym, że jego analiza była raczej projekcją pobożnych rosyjskich życzeń, a nie realnej oceny sytuacji politycznej. Choć z perspektywy czasu widzimy w tej symulacji pierwowzór nowego typu wojny - wojny hybrydowej.

Biskupski, Polak z pochodzenia, uważał, że Armia Czerwona zlikwiduje Polskę i przywróci granice z 1914 r., w czym miała pomagać partyzantka ukraińska atakując Polaków. Przeciwko Polakom również wystąpić mieli Białorusini chwilowo sprzymierzeni z (czerwoną) Moskwą („Białorusini zawrą przymierze z Moskwą i będą bić się z Polakami”). W chwili osiągnięcia przez Armię Czerwoną granicy z $1914 \mathrm{r}$. oficerowie Armii Czerwonej (w większości oficerowie starego reżimu) mieli otrzymać polecenie przeprowadzenia puczu i wprowadzenia dyktatury wojskowej. W tym momencie miała się rozpocząć ofensywa Wrangla pozostającego w stałym kontakcie $\mathrm{z}$ „Wojennym Centrum”. Wesprzeć ją mieli Ukraińcy, którzy - pod dowództwem oficerów „starego reżimu” - mieli napaść na komunistyczną armię od strony tyłów. Białorusini mieli z kolei zaprosić rosyjsko-niemieckich ochotników w celu oczyszczenia kraju od komunistów. Przewidywano masowe wybuchy powstań antykomu- 
nistycznych. Wszystkie te zdarzenia miały być uwieńczone ogłoszeniem przymierza Rosji, Niemiec i Węgier oraz przywróceniem trzech tronów ${ }^{20}$.

Projekt Biskupskiego (lipiec1920) wykluczał współpracę z tymi, którzy w przeszłości współpracowali z Polską, co można było zinterpretować w sposób z góry wykluczający Białorusinów (Paweł Aleksiuk był przecież członkiem Rady BRL, Piłsudski popierał politycznie i finansowo Radę Najwyższą, z Piłsudskim i Paderewskim niejednokrotnie rozmawiał Anton Łuckiewicz). Łatwo wydedukować, iż rząd BRL niezmiennie deklarujący chęć budowy własnej, bynajmniej nie monarchistycznej państwowości, po wykorzystaniu w odbudowie Imperium miał po prostu zostać wyeliminowany.

Dla obu stron - niemieckiej i rosyjskiej - w lecie 1920 r. przywoływani przez płk. Maxa Bauera i gen. Wasilija Biskupskiego Białorusini z założenia byli tylko przedmiotem, a nie podmiotem toczącej się rozgrywki z Józefem Piłsudskim i jego wizją Europy Wschodniej.

Pragmatyczni Niemcy, niejako przy okazji, zamierzali skonsumować zdeponowane u nich fundusze białoruskie (a nawet więcej, wziąć kredyt na konto Białorusi i obrócić go na swoje własne cele polityczne, bynajmniej niezbieżne $\mathrm{z}$ intencjami polityków białoruskich). Spłatę zamierzano pozostawić Białorusinom, traktując ją prawdopodobnie jako formę rekompensaty za koszty ponoszone przez Niemców na utrzymanie jeńców rosyjskich, którzy określali się mianem Białorusinów, za wieloletnie łożenie na utrzymywanie aktywności przedstawicieli BRL w Niemczech oraz za różne inne niemieckie nakłady (np. na Homan) na rzecz Białorusinów terenie b. WXL.

„Temat białoruski” wywołali Niemcy. Monarchiści rosyjscy uważali polityków BRL po prostu za rosyjskich poddanych i tzw. „sposobem” zamierzali wyegzekwować od Białorusinów pakiet obowiązków wobec odbudowywanego rosyjskiego Imperium.

\section{SPISEK MONARCHISTÓW EUROPEJSKICH}

\section{Memoriał Pułkownika Bauera zatwierdzony 22 czerwca 1920 r. w Budapeszcie tajną konferencją monarchistów}

\section{Główny cel}

Wszystkie państwa biorące udział:

20 Informacje zaczerpnęłam z dwóch dokumentów: (1.) Spisek Monarchistów Europejskich. Memoriał Pułkownika Bauera zatwierdzony 22 czerwca 1920 r. w Budapeszcie tajną Konferencją Monarchistów oraz (2.) Spisek Monarchistów Rosyjskich. Memoriał gen. Biskupskiego przedłożony w Budapeszcie dnia 8-13 lipca 1920 r. międzynarodowej tajnej konferencji monarchistów. RGWA Fond 461K, opis 1, teczka 3, k. 4-7v. 
Niemcy, Austrja, Rosja (również państwa ościenne - Ukraina i Białoruś), Bułgaria, Turcja, Irlandia, nanoszą [tak w oryg.] uderzenie możliwie jednocześnie w czasie, które musi być oznaczone i które naznacza się między jesienią i wiosną roku przyszłego. Przytem Węgry zostają w bojowej gotowości na możliwe wypadki i zamykają granice.

\section{Wypełnienia ogólne}

We wszystkich państwach istnieją juz organizacje, które zostają niezmienione. Jednakże zwoływany będzie ciągły Komitet Wykonawczy. Główna kwatera mieści sie w miejscu określonym przez Węgry i składa się z męża zaufania z prawem głosu decydującego, każdej biorącej udział grupy. Przewodnictwo (Hegemonia) należy się Niemcom (Bawarii). Wszystkie miejscowe detale regulują Węgry. Centralny Kom[itet] Wyk[onawczy] ma swoich przedstawicieli w państwach biorących udział, jak i również w innych ważniejszych państwach.

Zasilanie pieniędzmi jak niżej.

\section{Prasa}

Ważnem jest posiadanie jednolitego kierownictwa nad prasą. Dla tego też niezbędnem jest mieć Biuro prasowe przy Centr[alnym] Kom[itecie] Wyk[onawczym].

Nadzwyczajnie wpływać za pomocą tego biura na prasę $e^{21}$, która nam sympatyzuje. Tam, gdzie jeszcze prasa zorganizowaną nie jest, takową organizuje się $\mathrm{z}$ wypadku potrzeby.

\section{Organy wykonawcze}

Centralny Komitet Wykonawczy organizuje Ogólny Komitet Wykonawczy (wykorzystując przy tym istniejące już tajne organizacje) dla wycofania zdradzieckich lub niebezpiecznych elementów na rozkaz Centralnego Kom[itetu] Wyk[onawczego].

\section{Sprawa finansów}

Niezbędne sumy pieniężne wyszukuje możliwie każde z poszczególnych państw. Utrzymanie Centr[alnego] Kom[itetu] Wyk[onawczego], również i subsydia poszczególnym organizacjom, kierownikom, wydatki tajne (ochrona) pokrywa się pożyczką wewnętrzna Rządem Białej Rusi. (Drukowanie pieniędzy w Węgrzech). Do tego ustanawia się porozumienie między przedstawicielami Białej Rusi i Niemiec.

\section{Konspiracja i konfinencja}

Centr[alny] Kom[itet] Wyk[onawczy] zbiera się najmniej jeden raz w tygodniu, na każdem zebraniu, każdy z upełnomocnionych z pełną otwartością ogłasza, co się stało lub co się dzieje w reprezentowanym przez niego państwie, tak samo również

21 W oryginale charakterystyczna literówka „na pracę”. „C” w alfabecie rosyjskim to „s” w cyrylicznym. 
omawia się położenie ogólno-polityczne. Wszyscy uczestnicy pod przysięgą obowiązani są dotrzymywać tajemnicy. Naruszenie tajemnicy karane będzie śmiercią.

Wszystkie delegacje, również poszczególne osoby od rozmaitych państw, jakikolwiek bądź cel mające, powinny być bez uprzedniego wysłuchania przedstawione osobiście odpowiedniemu członkowi Centr[alnego] Kom[itetu] Wyk[onawczego].

\section{Bojowa gotowość przeciwko Entencie}

Siła wojskowa biorących udział musi być przywróconą, żeby, po pierwsze przeszkadzać wmięszaniu się Ententy do naszej akcji usunięcia rewolucyjnych elementów, po drugie, i to przede wszystkiem dlatego, żeby dosięgnąć zanulowania wszystkich tak zwanych rokowań pokojowych.

1) Organizacja osobnych wojskowych sił jest rzeczą danego państwa. Niemcy zaś po zaproszeniu, przedstawiają do organizacji i do osiągnięcia jednolitego formowania, odpowiednich oficerów, również dane o liczbie oficerów, utrzymania itd.

2) Broń i amunicja skupuje się przedstawicielami Niemiec (o ile zaś takowi są) w Niemczech przy pomocy prywatnych firm i rozdziela się odpowiednio w potrzebie. Płace regulują się odpowiednim państwom. Wskazówki kupna innemi sposobami, powinny być wykluczone. Dane o potrzebnej ilości broni, powinny być ogłoszone w możliwie najbliższym czasie.

3) Powinno przystąpić [się] do robienia nowej, specjalnej broni i amunicji. Niemcy, o ile same nie będą mogły dostarczyć broni, przedstawiają do rozporządzenia maszyny, surowiec i personel.

Rokowania prowadzą tylko przedstawiciele Niemiec, reszta zaś państw ogłasza, jakimi fabrykami rozporządza, mogących wziąć na siebie wypełnienie tych zadań - (ścisłe zamówienia na przesyłkę zagranicę), wskazówki na czasie, zgoda na konstrukcję broni i ilość żądanej broni.

\section{Ekonomiczne i polityczne porozumienie.}

1) Strony biorące udział, już teraz między sobą gwarantują zasady jak najbardziej opiekuńczej strony w stosunku [do] interesów utrzymującego /? /22

2) Rząd węgierski ustanawia, co ma w rozporządzeniu wykazu chleba, rogacizny, wina itd. ${ }^{23}$ Sam wywóz oddaje się w ręce niemiecko-węgierskiego prywatnego towarzystwa, które się tajnie zorganizuje i kontrolowane będzie przez Centr[alny] Kom[itet] Wyk[onawczy]

22 Prawdopodobnie chodzi o Niemcy. Patrz pkt II. 3: „Niemcy, o ile same nie będą mogły dostarczyć broni, przedstawiają do rozporządzenia maszyny, surowiec i personel”.

23 „Chleb, rogacizna, wino”... Przypuszczam, że był to szyfr oznaczający rodzaje uzbrojenia. 
3) Cele polityczne liczą się ustanowionymi dla Niemiec i Węgier, reszcie zaś będą one omówione potem w Centr[alnym] Kom[itecie] Wyk[onawczym]

4) Koniecznem jest mieć w widoku ochronienie Centr[alnego] Kom[itetu] Wyk[onawczego] w zmienionej (oficjalnej) formie i po osiągnięciu nakreślonych obecnie celów

\section{Sprawa wysiedlenia}

Dlatego, żeby uratować jak najlepsze oddziały niemieckie, które obecnie rozkładają się, bądź te do walki przeciwko winowajcom przewrotu, szczególnie w zagrożonych miejscowościach (ruchome rezerwy), bądź to do walk z Ententą, projektuje się emigrację.

Dlatego też rząd węgierski da pozwolenie na organizowanie przesiedlenia „Niemiecko-Węgierskiemu T[owarzystw]u Przesiedlenia”24, które powinno być utworzone z ograniczona odpowiedzialnością. Utworzenie jego powierza się niemieckim i węgierskim przedstawicielom Centr[alnego] Kom[itetu] Wyk[onawczego]. Towarzystwo pracuje zgodnie z tajnemi dyrektywami, wskazanemi przedstawicielom.

W związku z tym memoriałem był opracowany ostateczny plan wojskowy na podstawach niniejszych. Skoncentrować niemieckie wojska w Bawarii pod pozorem osób cywilnych. W Austrii przystąpić do energicznego przygotowania do kontrrewolucji, przy pomocy tutejszych organizacyj. Węgry maja koncentrować wojska w zach[odnich] Węgrzech. Niemieckie wojska przy pomocy organizacji Orgesz ${ }^{25}$, grupami powinny być przesłane do Austrii, żeby w odpowiedniej chwili wystąpić, będąc podtrzymywanymi austriackimi kontrrewolucyjnymi wojskami. Plan wojskowy był opracowany przez pułkownika Bauera ${ }^{26}$ i w głównych zarysach przedstawił się następująco:

Wskutek dobrego zorganizowania Karyntii ona na własna rękę przygotowuje kontrrewolucję u siebie. Prócz tego ona oddaje do rozporządzenia niemieckich oficerów 5 tysięcy ludzi. Oddziały niemieckie i 5 tysięcy ludzi z Karyntii skoncen-

24 Planowane „Niemiecko-Węgierskie Towarzystwo Przesiedlenia” wg dostępnych informacji ostatecznie nie zostało powołane do życia.

25 Georg Escherich (1870-1941) - niemiecki leśnik, nacjonalistyczny polityk i podróżnik (Afryka). W 1914 r. ranny na froncie zachodnim, następnie objął stanowisko. Został wojskowego zarządcy Puszczy Białowieskiej (do 28 grudnia 1918 r.), gdzie rozwijał rabunkową eksploatację drewna na potrzeby militarne Cesarstwa Niemieckiego. Powszechnie stał się znany w Niemczech około 1921 r. jako założyciel nacjonalistycznej „Organizacji Escherich” (w skrócie „Orgesch”), powstałej w związku z rewolucją listopadową i powstaniem w Monachium Republiki Radzieckiej. „Orgesch” był jedną z najsilniejszych paramilitarnych organizacji w Rzeszy Niemieckiej, a jej członkowie brali udział w walkach przeciwko powstańcom w III Powstaniu Śląskim. Zob. szerzej: G. Axhausen (Hrsg.), Organisation Escherich. Die Bewegung zur nationalen Einheitsfront, Weicher, Leipzig und Berlin 1921, ss. 80. Zob. też E. Rosen, Orgesch, Scherl, Berlin 1921, ss. 120.

26 W oryginale tekst brzmi - „pułkownikiem Bauerem”, co wskazuje na to, że język polski był dla tłumacza językiem obcym. 
trują się w /Steiermark/, ponieważ robotnicy tamtejsi dość dobrze zorganizowani i uzbrojeni. Organizacja Orgesz bierze na siebie Tyrol, Salzburg ${ }^{27}$, przy czym uzbrojenie tych dwóch prowincji zrobi Orgesz.

W oznaczonej chwili wszyscy wodzowie socjaldemokracji we wszystkich częściach Austrii powinni być aresztowani w swoich mieszkaniach i rozstrzelani.

Ażeby prezydent Żejc ${ }^{28}$ i dr Renner ${ }^{29}$ nie uciekli, była utworzona osobna organizacja dla Niższej Austrii i Wiednia. Prócz tego, było na widoku, że węgierscy oficerowie, którzy dobrze znają Wiedeń, powinni byli być odesłani tam, aby czekać w Wiedniu na początek akcji.

Komendanci Karyntii i Salzburga otrzymali zgodnie z planem pułkownika Bauera natychmiastowy rozkaz, zając oba wyjścia w tunelu między Karyntem i Salzburgiem, żeby Karyntia nie mogła być oderżnięta uzbrojonymi robotnikami ${ }^{30}$, którzy zgodnie z informacją, tam właśnie są dość silni. Wojska pruskie w Styrii będą musiały zająć Brucki Mur ${ }^{31}$ i postępować równolegle $\mathrm{z}$ węgierskimi wojskami na Wiedeń, jak tylko węgierskie wojska ze wsch[odnich] Węgier przejdą do Austrii. Jeżeliby zaś Czecho-Słowacja przedsięwzięła jakieś kroki zaczepne, to ją zaatakują Węgry ze strony Słowacji, a wojska pruskie ze strony........ [wykropkowanie w tekście - jgk].

Prócz tego w ciągu szeregu miesięcy z Niemiec skierowuje się w Deutschböhnen ruch, celem którego [jest] powstanie przeciw $\mathrm{Cz}$ [echo]Sł[owackiej] Rzeczypospolitej i Węgry podtrzymali tę organizację materialnie.

W obecnej chwili zabici powinni byli być przez tajną organizację ${ }^{32}$ kierownicy i polityczni działacze Czecho - Słowacji.

Publikowany tekst [tlumaczenie] przechowywany jest w Rosyjskim Głównym Wojennym Archiwum w Moskwie w tzw. Fondzie Trofiejnym. RGWA, Fond 460K, opis 1, t. 3, k. 4-5. Przed laty $z$ cała pewnościa widziałam ten sam Memoriał w zbiorach AAN $w$ Warszawie w postaci druku w języku polskim.

27 W oryg. Zalcburg.

28 Karl Seitz (1869-1950), austriacki polityk, pełnił urząd pierwszego prezydenta przez 21 miesięcy - od 5 marca 1919 do 9 grudnia 1920. Wiedeńczyk, socjaldemokrata. W 1902 r. wybrany do parlamentu prowincji Dolnej Austrii. W trakcie I WW w nielicznej grupie pacyfistów. Posłowie narodowości niemieckiej ogłosili się (21 X 1918) przedstawicielami ziem niemieckojęzycznych i Karl Seitz został jednym z trzech przewodniczących, a 30 października - głową państwa. 11 listopada, gdy cesarz Karol zrzekł się udziału w rządach, ogłoszono powstanie Republiki Niemieckiej Austrii i Seitz został jej prezydentem. H. D. Gröller, Karl Seitz - Ein Leben an Bruchlinien, Schmid, Wien (2005).

29 Karl Renner (1870-1950), socjaldemokrata austriacki, naukowiec socjolog prawa, jeden z teoretyków austromarksizmu. W latach 1918-1920 był pierwszym kanclerzem republikańskiej Austrii. S. Nasko, Karl Renner, [w:] Die Österreichischen Bundeskanzler. Leben und Werk. Hrsgb. V. F. Weissensteiner und E. Weinzierl, Österreichischer Bundesverlag, Wien 1983, s. 24-53.

30 Czytaj: odcięta przez uzbrojonych robotników.

31 Bruck an der Mur - miasteczko w środkowej Austrii, w Styrii u ujścia rzeki Mürz do Mury, ważny węzeł komunikacyjny z uwagi na położenie geograficzne.

32 W oryg. „tajną organizacją". 
(2)

\title{
SPISEK MONARCHISTÓW EUROPEISKICH
}

\section{Memoriał gen. Biskupskiego przedłożony w Budapeszcie dnia 8-13 lipca 1920 r. międzynarodowej tajnej konferencji monarchistów}

\author{
ŚCIŚLE TAJNE
}

\section{Memoriał Nr 18 lipca $1920 \mathrm{r}$.}

\section{Wstęp}

Kiedy w końcu 1916 r[oku] [i] w początkach 1917 r[oku] rosyjskie partie monarchistów i najbardziej przewidująca część z najbliższego otoczenia cesarza rosyjskiego zrozumieli zupełnie dokładnie, że ciąg dalszy wojny z Niemcami zakończy się katastrofą obu państw i dwóch królestw i kiedy te same idee dojrzały w kołach monarchistów i prawdziwych patryotów Niemiec, Anglia była prędko poinformowaną o niebezpieczeństwie, postanowionym więc było wywołać w Rosji przewrót burżuazyjny, który i wybuchł.

Władza przeszła w ręce „Rządu Tymczasowego”, który jak my widzimy hasło „Wierność Entencie” stawił wyżej hasła „wierność ojczyźnie”. Kiedy wyznawcy Ententy władzę pochwycili w ręce, Niemcy byli zmuszeni zrobić wszystko możliwe, żeby złamać siłę armii rosyjskiej, nie zastanawiając się nad najbardziej stanowczymi krokami. Wówczas właśnie to były wynalezione „intellektualne gazy”- bolszewizm.

Armia rosyjska zginęła, jak pod dotknięciem różdżki czarodziejskiej. Jednak wojnę Niemcy przegrali i wówczas Anglia korzystając z okoliczności postanowiła zlikwidować Rosję. Pod pretekstem pomocy „białym armiom” w rzeczywistości chciano osiągnąć cel zawładnięcia Rosją jako kolonią Ententy, szczególnie Anglii. Denikin - produkt Rządu Tymczasowego $\mathrm{w}$ dalszym ciągu prowadził politykę „wierności” Entencie w każdym razie.

Rezultatem tego było przedłużenie wojny światowej do doby obecnej na terytorium rosyjskim i na rachunek Rosji.

Grupy monarchistyczne, generałowie cesarza i większa część ludności rosyjskiej wiedza dobrze, ze te katastrofalne położenie może się skończyć tylko w tym wypadku, jeżeli zwyciężone narody zawrą między sobą tajne sprzymierze, wyłoniwszy ogólny program zacząwszy jak najdalej aktywną politykę.

Wielka Rosja, Wielkie Niemcy i Wielkie Węgry związane z sobą ekonomicznie i politycznie - oto jedyny ratunek w naszym położeniu bez wyjścia.

Postawiwszy więc ten cel trzeba natychmiast opracować program i działać. Nie trzeba polityki gabinetu, polityki ustępstw i czczych ${ }^{33}$ rozmów - nic prócz działania.

33 Wiele wskazuje na to, że tłumacz był cudzoziemcem - w oryg. „tszczych” zamiast „czczych”. 
I można być pewnym, że w momencie, kiedy Europa po tej okropnej wojnie przeszła w stan moralnej indolencji / szczególnie zwycięzcy/ zjednoczona i aktywna polityka zwyciężonych nie napotka jakiegokolwiek aktywnego oporu na serio.

\section{ORGANIZACJA}

Co się tyczy sprawy rosyjskiej my przypuszczamy, ze trzeba działać w sposób następujący:

1) W stolicy jednego $z$ państw, wchodzących $w$ spisek trzeba będzie zorganizować „Wojenny Centr”, który będzie podtrzymany przez „Centr polityczny” składający się z wodzów rosyjskich klubów monarchistycznych.

„Wojenny Centr” wejdzie natychmiast w kontakt $\mathrm{z}$ rozmaitymi siłami wojskowymi operującymi w rosyjskiej wojnie obywatelskiej (jednakowoż z białymi, czerwonymi, zielonymi, separatystami, wykluczając tych którzy pracują z Polską itd.)

2) W tym czasie „Centr polityczny”, działając w ścisłym kontakcie z „Wojennym Centrum" zwiąże sie z monarchistycznymi partiami rozproszonymi po całej Rosji i Europie, przedkładają im jednakowy dla wszystkich program działania i propagandy.

3) Biali ochotnicy rozproszeni w Estonii, w Niemczech, w Serbii, w Polsce, po oczyszczeniu z elementów niemonarchistycznych i skazanych [skażonych ?-jgk], powinno być zebrane $\mathrm{w}$ jednem $\mathrm{z}$ państw nowego sprzymierza, aby móc zorganizować kadry nowej armii, żandarmerii i policji w przyszłej Rosji.

Otrzymując wsparcie, prowiant, umundurowanie od państwowego sprzymierza, wszyscy ci ludzie będą zwolennikami nowej kombinacji politycznej.

4) Z działaczy politycznych Ukrainy, Białej Rusi, Litwy i nawet Łotwy będą przyciągnięte do tejże roboty wszystkie niezbędne elementy, [ludzie] którzy wykorzystają swój wpływ, wpływ organizacji podległych, dla współpracy w urzeczywistnieniu ogólnych planów.

Samo przez się [się] rozumie, oni nie będą w łączności $\mathrm{z}$ „Centrum Monarchistycznym”. Detale tej roboty będą organizowane /siront organise/ „Centrem Wojskowym" przez pośrednictwo wiernych współpracowników, których dowództwo wojskowe ma w każdym z tych Państw. Osoby te i ich prace będą podtrzymywane niezbędnymi sumami, co trzeba działać natychmiast.

Zatem ogólny plan będzie mniej więcej następujący:

\section{PLAN OGÓLNY}

1) Armia czerwona zlikwiduje Polskę i przywróci granicę 1914 roku.

2) Armia Wrangla będzie przytrzymywać się taktyki obronnej do tego czasu, kiedy granice 1914 r. będą ustanowione czerwoną armią.

3) Partyzantki ukraińskie będą się bić z Polakami 
4) Białorusini zawrą sprzymierze z Moskwą i będą bić się z Polakami

Kiedy granice [granice 1914 r. - jgk] będą ustanowione

5) D[owód]cy, oficerowie armii czerwonej /w masie oficerowie starego reżymu/ będą powołani do /Putsch/ i dla wprowadzenia dyktatury wojskowej.

6) Wrangel rozpocznie ofenzywę w kontakcie $z$ „Centrem wojennym”

7) Armie państw centralnych będą zmobilizowane przed grozą bolszewizmu i zaatakują armią komunistyczną - mając jako awangardę rosyjskie białe wojska. Naród będzie przygotowany propagandą i rozdawaniem pieniędzy rosyjskich w ilości nieograniczonej w celu podjęcia antykomunistycznego powstania w tyłach komunistycznej armii.

8) Ukraińcy partyzanci pod dowództwem oficerów starego reżymu napadną z tyłu na komunistyczną armię

9) Białoruś zaprosi rosyjsko-niemieckich ochotników, żeby oczyścić kraj od komunistów.

10) Biali, znajdujący się w czerwonej armii, wywołają powstania w stolicach, zaproszą rosyjsko-niemiecko-węgierskich ochotników dla utworzenia porządku cywilnego.

11) Będzie ogłoszone sprzymierze Rosji, Niemiec, Węgier na podstawach jednakoż sprzyjających dla trzech państw, obiecujący trwały pokój i obopólny rozkwit ekonomiczny.

12) Trony będą przywrócone i respublikańskie państwa będą doprowadzone do położenia na jakie zasługują.

Ale do tego niezbędnie potrzeba działać natychmiast i zupełnie konspiracyjnie i także posiadać nieograniczoną ilość pieniędzy - do tego wszystkie środki są dobre.

Nie trzeba zapominać, że nasi wrogowie mogą poprzedzić nas, ponieważ już Anglia opracowuje plan wspólny z organizacjami białych i czerwonych. Organizacje te, robiące w ciągu 8-iu miesięcy bezowocne wysiłki, aby otrzymać pomoc z Niemiec (jak i Rząd Białej Rusi) przychodzą do rozpaczy i mogą być zmuszeni rzucić się w objęcia Anglików, niestety nie rozumiejąc, że byłoby to śmiercią idei Wielkiej Rosji i monarchii. Ale brak innego wyjścia, każdy stracony dzień może się stać decydującym.

\section{ZAKOŃCZENIE}

Dlatego, żeby zreasumować ten krótki memoriał, który szkicuje tylko obraz przyszłej pracy, trzeba dodać, ze rosyjska grupa /ludzie wierzą wziąwszy na siebie inicjatywę/ zupełnie przygotowaną jest działać około 4-5 miesięcy, ale stanowisko Niemiec, brak orientacji politycznej w Niemieckim Rządzie, nieporozumienia między rozmaitemi partiami politycznemi Niemiec, osobiste intrygi, w końcu nie sposób pracować 
z takiemi osobami jak Denikin ${ }^{34}$, Judenicz ${ }^{35}$ i Szczerbaczow ${ }^{36}$ - wszystko to nie pozwalało inicjatorom prowadzić pracę w koniecznym zakresie. Pomimo wszystko, będąc zupełnie izolowanym, nie mając prawie żadnych materialnych warunków, oni zrobili całą przedwstępną pracę.

1. „Wojskowy Centr” w Berlinie funkcjonuje.

2. Polityczna grupa $z$ dniem dzisiejszym wyłoniła się.

3. Rząd Białej Rusi jest w kontakcie z Naczelnym Dowództwem „Wojskowego Centra".

4. Szczątki Białych armii-również.

5. Partyzanci ukraińscy w zasadzie przyłączyli się.

6. Baron Wrangel ${ }^{37}$, będący osobistym przyjacielem jednego z inicjatorów, przyjmie $\mathrm{w}$ tych dniach specjalnego kuriera osobę, spotkaną pełnomocnictwami Naczelnego Dowództwa „Wojskowego Centra”.

[7] Pytanie o rosyjskich pieniądzach dla propagandy i wydatków w Rosji w zasadzie rozstrzygnięte.

8. Przedwstępne omówienia z przedstawicielami czerwonego sztabu generalnego /czerwonego z wyglądu, faktycznie białego/ miały miejsce w maju [1920 - jgk].

Lecz wszystko to robiło się dotychczas w bardzo skromnych rozmiarach i ramkach.

34 Denikin Anton Iwanowicz (1872-1947). Generał-lejtnant. Głównodowodzący Armia Ochotniczą. 22 III 1920 na angielskim stawiaczu min odpłynął na wygnanie.

35 Judenicz Nikołaj Nikołajewicz (1862-1933) urodzony w rodzinie szlacheckiej guberni mińskiej. 3 marca 1917 został wyznaczony na stanowisko naczelnego dowódcy Samodzielnej Armii Kaukazu, a po zorganizowaniu dowódcą Frontu Kaukaskiego. Nie zdecydował się prowadzić operacji zaczepnych. 31 maja został zdjęty ze stanowiska i przeniesiony do dyspozycji ministra wojny. W listopadzie 1918 emigrował do Finlandii. W maju 1919 utworzył „Konsylium polityczne”. 24 maja 1919 na prośbę admirała Aleksandra Kołczaka został dowódcą wszystkich rosyjskich sił na Północnym Zachodzie, a 10 czerwca został wyznaczony przez Kołczaka naczelnym dowódcą Wojsk Północno-Zachodnich. W sierpniu wszedł w skład Rządu Północno-Zachodniego. 28 września wojska Judenicza przerwały front 7 Armii Czerwonej. Od 2 października do 28 listopada 1919 był naczelnym dowódcą Białej Armii Północno-Zachodniej. Wobec natarcia Armii Czerwonej (XI 1919), zmuszony do odwrotu i wycofania się do Estonii, gdzie armia została rozbrojona. Na początku roku 1920 na żądanie ze strony Estonii ewakuacji z estońskiego terytorium w pośpiechu zorganizował atak na Piotrogród i Psków. Biali zostali jednak odrzuceni, uratowała ich brytyjska flota. W styczniu 1920 Judenicz został aresztowany przez gen. majora Stanisława Bułak-Bałachowicza, ponieważ w obliczu klęski nie chciał wypłacić swoim żołnierzom zaległego żołdu. Zwolniony, udał się na emigrację do Francji, w której mieszkał do końca życia. Nie jest wykluczone, że został otruty przez GRU.

36 Szczerbaczow Dmitrij generał, szef paryskiej wojskowej placówki rosyjskiej, łącznik między wszystkimi armiami walczącymi z bolszewikami.

37 Wrangel Piotr Nikołajewicz, baron (1878-1928), pochodził ze starego rodu skandynawskiego pochodzenia. Przed przewrotem październikowym dowódca korpusu kawaleryjskiego. Od 22 III 1920 przejął od Denikina dowództwo nad Siłami Zbrojnymi Południa Rosji (przemianowanymi następnie na Armię Rosyjską). W listopadzie 1920 ewakuował armię z Krymu do Konstantynopola. W latach 1922-1923 Armia Rosyjska została przeprowadzona do Jugosławii. Na emigracji założył w roku 1924 Ogólnorosyjski Związek Wojskowy. W roku 1926 osiedlił się w Belgii. Na emigracji pracował jako inżynier górniczy. Zmarł w Brukseli z powodu gruźlicy. Córka utrzymywała, że za jego śmierć odpowiedzialne były radzieckie służby specjalne. 
W chwili, kiedy środki materialne będą znalezione w dostatecznej ilości, kiedy plan będzie zatwierdzony, cała praca będzie puszczoną w ruch $\mathrm{z}$ całą szybkością i partie związane z Centrum będą działać nie obawiając się porażki

Podkreślmy tylko, że zgrupowanie białych kadr w odpowiedniej [aktualnej? jgk] chwili, niestety, znajduje się w opłakanym stanie.

Każdego dnia tracimy elementy, a ważności sprawy, oczywista i czasu, tracić nie można.

Reszta zaś może być lekko zrobioną, jeżeli wyżej wymieniony plan będzie zatwierdzony i przyjęty, i inicjatorom tego planu będą dane odpowiednie środki.

W tym czasie specjalnie dobrane i wydyscyplinowane oddziały wraz z żandarmerią i policją wymienione w paragrafie 3 będą rzucone prosto pociągami do stolic, aby powstrzymać nowy rząd, wesprzeć powstańców, utrzymać porządek cywilny i dyscyplinę z mocnym postanowieniem „zwyciężyć albo umrzeć”.

Publikowany tekst [tłumaczenie] przechowywany jest w Rosyjskim Głównym Wojennym Archiwum w Moskwie w tzw. Fondzie Trofiejnym. RGWA, Fond 460K, opis 1, t. 3, k. 6-7v.

Monarchists and their political simulations in May-July 1920. Memorials by Colonel Max Bauer and General Vasiliy Biskupskiy

In 1920, the alliance of German monarchists (including Baltic Germans) with their Russian counterparts residing in Germany was inevitable. In the event of Soviet influence getting deterred, the sole competitors for both Germans and Russians in their desire to take over the role of moderator in the territories of the former Grand Duchy of Lithuania were Poles.

Among the allies of the "conspiracy of European monarchists", conceived in May 1920 at the initiative of the German side, were - aside from Germany and Austria - "Russia with its neighbouring countries, that is Ukraine and Belarus", as well as Bulgaria, Turkey, Ireland and Hungary. The document signed by Colonel Max Bauer was already in the making in May 1920, that is before the subordination of the Civilian Administration of Eastern Territories to the Council of Ministers (1 June 1920), which crowned the efforts of the Polish incorporationist camp, and before the extension of the jurisdiction of the Supreme Audit Office in Warsaw over the Eastern lands.

By initiating the formation of a coalition directed against not only the Bolsheviks, but also Polish interests, the German side (as Colonel of General Staff Max Bauer cannot be considered solely a "monarchist") not only duped the Russian monarchists, but also treated the Berlin-based politicians of the Belarusian Popular Republic, who idealised the attitude of German politicians towards Belarus, rather instrumentally.

In response to the new military and geopolitical situation, Vasiliy Biskupskiy, leader of the Russian monarchists, decided to present a different project, rival to the German one, at the subsequent monarchist conference (8-13 July 1920, Budapest); however, the document proved to be more of a political prophecy, as it had little in common with the actual political situation.

The efforts of the monarchists were supposed to be crowned with the announcement of a covenant between Russia, Germany and Hungary and the restoration of the three thrones. In Biskupskiy's memorial, Russia's "neighbouring countries", i.e. Belarus and Ukraine, were not longer mentioned. This memorial did not meet with any political counteraction by the German 
side. From this point forward, the monarchist movement would in fact function as a somewhat "vanity fueled" movement dominated by Russians.

In the summer of 1920, the inhabitants of the former Grand Duchy of Lithuania were, for both Germans and Russians, merely an object, rather than the subject, in their ongoing struggle; the struggle against not only Bolshevik Russia, but also the White Russian-German rivalry with Józef Piłsudski and his vision for Europe.

Translated by Jakub Perliński

\section{Монархисты и их политические симуляции в мае-июле 1920 года. Докладные записки («мемориалы») плк. Макса Бауэра и ген. Василия Бискупского}

В 1920 году альянс немецких монархистов (включая прибалтийских немцев) и российских монархистов, находящихся на территории Германии был неизбежен. Как для немцев, так и для русских, соперником в перехвате роли модератора на землях бывшего Великого Княжества Литовского, в случае вытеснения влияний Советской России, могли стать лишь поляки.

Акционерами, образованного в мае 1920г. по немецкой инициативе „Заговора Европейских монархистов” были, кроме Германии и Австрии, Россия „с соседними государствами - Украиной и Белоруссией”, а также Болгария, Турция, Ирландия и Венгрия. Труд, подписанный полк. Максом Бауэром, был создан еще в мае 1920г. то есть до подчинения Гражданского управления Восточных земель Совету Министров в Варшаве, венчающего усилия польского инкорпорационного лагеря (1 VI 1920) и до распространения на Восточные земли юрисдикции варшавской Высшей контрольной палаты.

Немцы (сложно считать полковника генштаба Бауэра исключительно „монархистом”), ыступая с инициативой образования коалиции, направленной не только против большевиков, но и против польских интересов, не только „обыграли” российских монархистов, но и очень инструментально отнеслись к берлинским политикам Белорусской Народной Республики, идеализирующим отношение немецких политиков к Белой Руси.

В изменившемся военном и геополитическом положении, на очередной монархической конференции (8-13 июля 1920, Будапешт) лидер берлинских российских монархистов Василий Бискупский представил проект, конкурентный немецкому, обладавший свойствами политического пророчества, но зато не имевший много общего с реальным политическим положением. Усилия монархистов должны были увенчаться объявлением о союзе России, Германии и Венгрии, а также восстановлением трех престолов. В докладной записке Бискупского уже не упоминались „соседние страны” России - Белоруссия и Украина. Эта докладная записка не встретился ни с какой немецкой политической контракцией. С тех пор монархическое движение de facto превратилось в движение, по сути, немного „звездное”, в котором доминировали русские.

Для обеих сторон - немецкой и российской - летом 1920г. жители земель бывшего Великого Княжества Литовского были лишь объектом, а не субъектом, шедшей борьбы. Борьбы не только с большевистской Россией, но и белогвардейско-немецкого розыгрыша с Юзефом Пилсудским и его видением Европы. 


\section{Bibliografia:}

Axhausen G. (Hrsg.), Organisation Escherich. Die Bewegung zur nationalen Einheitsfront. Weicher, Leipzig und Berlin 1921.

Fox J. P., Max Bauer: Chiang Kai-Shek's First German Military Adviser, „Journal of Contemporary History” Vol. 5 (No 4) (October 1970), p. 21-44.

Gierowska-Kałłaur J., „Depozyty” Walerego Sławka przechowywane w Moskwie. („Biuro Detaszowane Oddziału II Naczelnego Dowództwa 1919”), „Studia z Dziejów Rosji i Europy Środkowo-Wschodniej" 47, 2012, s. 208-272.

Gierowska-Kałłaur J., Question of the access of restored Polish State to the Baltic See in opposition to German interests. Marea Loc al Memoriei si al Desfasurarilor Geostrategice. Asociatia pentru Dialog Intercultural si Studii Istorice, red. Florin Anghel, Gabriel Stalian Manea, Metin Omer, Editura CETATEA se SCAUN, Targoviste 2014, p. 225-238.

Gierowska-Kałłaur J., Zarząd Cywilny Ziem Wschodnich (9 lutego 1919-9 września 1920), Wydawnictwo Neriton \& Instytut Historii PAN, Warszawa 2003.

Gröller H. D., Karl Seitz - Ein Leben an Bruchlinien, Schmid, Wien (2005).

Łossowski P., Konflikt polsko-litewski 1918-1920, Warszawa 1996.

Mędrzecki W., Niemiecka interwencja militarna na Ukrainie w 1918 r., DiG, Warszawa 2000.

Nasko S., Karl Renner W. Die Österreichischen Bundeskanzler. Leben und Werk, Hrsgb. V. F. Weissensteiner und E. Weinzierl, Österreichischer Bundesverlag, Wien 1983, s. 24-53.

Orlik Z. [oprac.], Gmach Generalnej Dyrekcji Dóbr Książęcych w Pszczynie - http://www.biurogk. com/gmach_palais_historia.html.

Rosen S. E., Orgesch. Scherl, Berlin 1921.

Schwertfeger B., Bauer Max, [w:] Neue Deutsche Biographie (NDB). Band 1, Duncker \&Humblot, Berlin 1953.

Vogt A., Oberst Max Bauer. Generalstabsoffizier im Zwielicht. 1869-1929, Biblio Verlag, Osnabrück 1974 (Studien zur Militärgeschichte, Militärwissenschaft und Konfliktforschung 6).

Wołkow S. W., Generaty i sztab-oficery russkoj armii. Opyt martirologa, Tom 1, Moskwa 2012.

dr hab. Joanna Gierowska-Kałłaur - profesor IH PAN (Zakład Historii Europy Wschodniej i Studiów nad Imperiami XIX i XX wieku) specjalizuje się w wyszukiwaniu i edycji źródeł. Jest również wykładowcą Studium Europy Wschodniej Uniwersytetu Warszawskiego. Pracuje obecnie m.in. nad opartą w dominującej części na niepublikowanych materiałach archiwalnych ze zbiorów NDWP w Moskwie pracą „Bardzo krótki zarys zagadnienia białorosyjskiego”. (j.gierowska-kallaur@uw.edu.pl) 